\title{
The Effects of Learning-Style Based Activities on Students' Reading Comprehension Skills and Self-Efficacy Perceptions in English Foreign Language Classes
}

\author{
Özgül Balc1 ${ }^{1}$ \\ ${ }^{1}$ School of Foreign Languages, Necmettin Erbakan University, Konya, Turkey \\ Correspondence: Özgül Balcı, School of Foreign Languages, Necmettin Erbakan University, Konya, Turkey. \\ E-mail: obalci@konya.edu.tr
}

Received: September 23, 2017

Accepted: September 30, 2017 Online Published: October 23, 2017

doi:10.5539/hes.v7n4p35

URL: http://doi.org/10.5539/hes.v7n4p35

\begin{abstract}
This study investigated the effects of learning-style based activities on students' reading comprehension skills and self-efficacy perceptions in English foreign language classes. A quasi-experimental, matching-only pretest-posttest control group design was utilized. The study was conducted with freshmen university students majoring in Elementary Mathematics Education at Necmettin Erbakan University in the fall semester of academic year 2012-2013. English was one of their compulsory courses and their self-reported language level was A1/A2 in terms of the self-assessment grid included in the Language Passport which is one of the three components of the European Language Portfolio. A total of 39 students in the experimental group and 39 in the control group participated in the study. The learning-style based activities were implemented in the experimental group, while the control group continued with routine classroom instruction without any attention to their learning styles. Both groups received three one-hour sessions weekly, for a total of eight weeks. Both the Reading Comprehension post-test scores and the Self-Efficacy Scale for English post-test scores were significantly different in favor of the experimental group. Also, a significant moderate positive correlation was found between English reading comprehension achievement and English self-efficacy. It can be concluded that learning-style based activities enhanced reading comprehension skills and English self-efficacy perceptions during this study.
\end{abstract}

Keywords: learning styles, learning-style based activities, reading comprehension skills, English self-efficacy perception

\section{Introduction}

Foreign language education has become a priority issue in line with the increasing importance of education in today's globalized world (Ceylan \& Yorulmaz, 2010). The English language has become prominent in all fields in almost every part of the world and has become the lingua franca in many professional and scientific settings (Gündoğdu, 2005). There is a growing awareness of the importance of foreign language education in Turkey as well, and the efforts for increasing the quality of foreign language education have been growing over the past few years. In fact, ensuring quality foreign language education is one of the indispensable prerequisites for training qualified individuals during the European Union accession period (Gömleksiz, 2002) that applies to the issue of Turkish membership of the European Union. Although foreign language education has a significant place in the country's education system, it is still a highly-disputed issue which needs to be urgently resolved. Despite being taught as a compulsory subject in primary, secondary, and higher education institutions, students have not been able to become competent in using the language effectively and efficiently on a large scale in real life situations. Outcomes are far from satisfactory and the desired level of achievement has not been reached. These ongoing problems in foreign language education in Turkey have been emphasized in many studies (e.g., Aktaş, 2004; Bülbül, 2009; Genç, 2003; Gömleksiz \& Elald1, 2011; Gömleksiz \& Sertdemir Düşmez, 2005; Güler, 2005; Işık, 2011; Karakaya, 2007; Üstünlüoğlu, 2008). Not taking individual differences into consideration is thought to be one of the underlying reasons for the inadequacies of foreign language education (Gömleksiz \& Sertdemir Düşmez, 2005). Even though individual differences have been emphasized and are of great importance in the education system, these differences seem to be ignored in practice (Ekici, 2003). 
It is emphasized in the literature that reading is a fundamental skill that contributes to language development, especially for additional language learners. Villanueva de Debat (2006) is one of the researchers who emphasizes the importance of reading for learners of English as an additional language. According to Grabe (2009), it is remarkable that many people around the world have learned to read in more than one language for different purposes; in addition, the author emphasizes the importance of reading by indicating that it is one of the few ways students can develop their language abilities to a point where they can reach their academic goals. Additionally, for English as additional language learners, the ability to read academic texts is thought to be one of the most important skills that should be acquired (Levine, Ferenz, \& Reves, 2000). Reading in an additional language is considered to be more challenging than it is in a first language as the reader often does not have adequate vocabulary knowledge, cultural background information, and sentence structuring ability, all of which play a key role in reading comprehension (Er, 2005).

With the increasing emphasis on education throughout the world, new trends and approaches to education have been emerging. Today, one of the issues emphasized by researchers and educators is designing learner-centered learning environments in which individual differences are considered. The significant role of individual differences in additional language learning has been articulated by researchers in the related literature (Oxford \& Ehrman, 1992; Rossi-Le, 1995; Skehan, 1989). Learning styles are one of the main aspects of individual differences affecting performance and should be taken into account in the design and delivery of courses in additional language learning as they are in other fields (Carrell, Prince, \& Astika, 1996; Oxford, 1989). In particular, perceptual learning styles have been neglected by researchers in the area of additional language education despite being vital (Rossi-Le, 1995).

Taking the literature on the role of affective factors in language teaching and learning field into account, it can be said that self-efficacy with other affective variables must be considered along with cognitive factors in additional language learning-teaching process. For example, Hanc1 Yanar and Bümen (2012) revealed that it is important to take affective factors such as attitude, motivation and self-efficacy into consideration in language learning environments and education programs. Ehrman, Leaver and Oxford (2003) indicate that motivation, self-efficacy, tolerance of ambiguity and anxiety are some of the affective factors that affect language learning-teaching process. According to Mills, Pajares, and Herron (2006), low self-efficacy influences students' performances in additional language classrooms.

Although the concept of student-centered education in which individual differences are taken into account has been adopted within educational settings in Turkey, there still appears to be problems in practice (Özpolat, 2013). Regarding this topic, further studies are needed to fully determine the role of individual differences in foreign language learning processes. This research aimed to investigate the effects of student-centered learning experiences regarding students' learning styles on their reading comprehension skills and self-efficacy perceptions in English foreign language classes. The results of this study are expected to provide a new perspective in relation to the problems in foreign language education and to also contribute to curriculum development studies, learning-teaching practices, and the literature in the field of foreign language teaching. Taking into consideration these problems, we looked for an answer to the following question:

"What are the effects of learning-style based activities on students' reading comprehension skills and self-efficacy perceptions in English foreign language classes?"

Based on the general purposes of the study, the following three hypotheses were formulated:

1) Learning-style based activities improve reading comprehension achievement over traditional reading comprehension activities.

2) Learning-style based activities improve English self-efficacy perception over traditional reading comprehension activities.

3) There are positive correlations between English reading comprehension achievement and English self-efficacy.

\section{Methodology}

\subsection{Research Design}

The matching-only pretest-posttest control group design as a type of quasi-experimental design was employed to investigate the effects of learning-style based activities on students' reading comprehension skills and self-efficacy perceptions in English foreign language classes. In quasi-experimental research design, groups, rather than individuals, are randomly assigned to the different treatments; however, the researcher still matches the subjects in the experimental and control groups on certain variables (Fraenkel, Wallen, \& Hyun, 2012). 
This study was carried out on two groups: an experimental group and a control group. After the groups had been randomly assigned to the different treatments, the subjects in the experimental and control groups were matched on certain variables (English Reading Comprehension Test scores, Self-Efficacy Scale for English scores, students' learning styles determined by Maggie McVay Lynch Learning Style Inventory, and students' backgrounds in English determined by the English Proficiency Background Form). The learning-style based activities (see page 7 for more information) were implemented in the experimental group, while the control group continued to work in a traditional way without any attention paid to learning styles. Both groups were taught during three one-hour sessions weekly, for a total of eight weeks.

In this study, "traditional reading comprehension activities" refers to the activities in which students' individual learning styles are not taken into consideration. Also, in the literature (Al-Hajaya \& Al-Khresheh, 2012; Baturay \& Akar, 2007; Gömleksiz \& Elald1, 2011; Güngör \& Ün Açıkgöz, 2005) traditional reading classes are described in a similar way in which students' learning styles are not taken into account. These classes are also described as teacher-centered, teacher-talk dominated, and a routine process. They include reading of the text by the teacher and some students, vocabulary exercises, and answering reading comprehension questions in a passive way.

\subsection{Participants}

The current study was conducted among freshmen university students majoring in Elementary Mathematics Education in the fall semester of the 2012-2013 academic year at Necmettin Erbakan University. There were 39 students ( 32 female and 7 male) in the control group and 39 (32 female and 7 male) in the experimental group for a total of 78 students participated in the study. Every student enrolled in this program is required to take Foreign Language I \& II (English) classes in their first academic year. Groups were randomly assigned to the different treatments. Although students were informed about the nature of the study, they were unaware as to whether they were in the experimental or control group. In addition, at the beginning of the study, they were asked to sign a consent form for participation.

The subjects in the experimental and control groups were matched on certain variables using the data obtained from following data collection tools:

1) The English Reading Comprehension pre-test scores

2) Self-Efficacy Scale for English pre-test scores

3) Maggie McVay Lynch Learning Style Inventory

4) English Proficiency Background Form

The English Reading Comprehension pre-test and Self-Efficacy Scale for English pre-test were analyzed by independent samples $\mathrm{t}$ test. Maggie McVay Lynch Learning Style Inventory and English Proficiency Background Form were analyzed by descriptive statistical techniques.

The reading comprehension pre-test results for both groups are provided in Table 1 below. As Table 1 shows, reading comprehension pre-test results for both groups did not reveal any statistically significant differences $(p>0.05)$ between the two groups, indicating that the participants both had similar reading comprehension performance before the application of the experiment.

Table 1. Reading comprehension pre-test results for both groups

\begin{tabular}{cccccc}
\hline Groups & Mean & \pm & SD & t & p \\
\hline Control & 14.95 & \pm & 5.32 & 0.96 & 0.34 \\
Experimental & 16.03 & \pm & 4.58 & & \\
\hline
\end{tabular}

Self-Efficacy Scale for English pre-test results for each of the four separate sub-dimensions and the total scale for both groups are given in Table 2 below. As Table 2 shows, the Self-Efficacy Scale for English pre-test results for each of the four separate sub-dimensions and the total scale for both groups did not reveal any statistically significant differences $(p>0.05)$ between the two groups, indicating that the participants both had similar self-efficacy levels regarding English before the application of the experiment. 
Table 2. Self-Efficacy Scale for English pre-test scores for both groups

\begin{tabular}{|c|c|c|c|c|c|c|}
\hline & Groups & Mean & \pm & SD & $\mathbf{t}$ & $\mathbf{p}$ \\
\hline \multirow{2}{*}{ Reading } & Control & 19.31 & \pm & 4.82 & \multirow{2}{*}{-0.09} & \multirow{2}{*}{0.93} \\
\hline & Experimental & 19.41 & \pm & 4.78 & & \\
\hline \multirow{2}{*}{ Writing } & Control & 21.67 & \pm & 6.61 & \multirow{2}{*}{-0.25} & \multirow{2}{*}{0.81} \\
\hline & Experimental & 22.03 & \pm & 6.26 & & \\
\hline \multirow{2}{*}{ Listening } & Control & 23.54 & \pm & 7.24 & \multirow{2}{*}{0.80} & \multirow{2}{*}{0.43} \\
\hline & Experimental & 22.33 & \pm & 6.09 & & \\
\hline \multirow{2}{*}{ Speaking } & Control & 13.21 & \pm & 4.36 & \multirow{2}{*}{-0.08} & \multirow{2}{*}{0.94} \\
\hline & Experimental & 13.28 & \pm & 4.22 & & \\
\hline \multirow{2}{*}{ Total } & Control & 77.72 & \pm & 20.61 & \multirow{2}{*}{0.15} & \multirow{2}{*}{0.88} \\
\hline & Experimental & 77.05 & \pm & 18.70 & & \\
\hline
\end{tabular}

Maggie McVay Lynch Learning Style Inventory results for both groups are shown in Table 3 below. The results show that learning style preferences were similar in both groups. Visual learning style was by far the most popular learning style, followed by the Kinesthetic and Auditory learning styles in both groups. According to Oxford (1995), the perceptual learning style is one of the most distinct learning style dimensions. In the literature, perceptual channels are often called modalities (Kinsella, 1995). Visual learners learn best through sight, auditory learners learn best through hearing, and kinesthetic learners learn best through movement and touch (Reid, 1995). According to Kinsella (1995), visual tools such as pictures, charts, diagrams, and tables help visual learners; auditory learners generally prefer listening to lectures, tapes and films, group activities, and individual talks; while kinesthetic learners tend to benefit most from field trips, role-plays, pantomime, and interviews.

Table 3. Learning style preferences of both groups

\begin{tabular}{lcccc}
\hline & \multicolumn{2}{c}{ Experimental } & \multicolumn{2}{c}{ Control } \\
\cline { 2 - 5 } & f & \% & f & \% \\
\hline Visual Learning Style & 24 & 61.54 & 25 & 64.10 \\
Auditory Learning Style & 4 & 10.26 & 6 & 15.38 \\
Kinesthetic Learning Style & 11 & 28.20 & 8 & 20.52 \\
\hline
\end{tabular}

According to the English Proficiency Background Form results, the average age of the control group was $18.33 \pm 0.74$ years while that of the experimental group was $18.49 \pm 0.64$ years and both groups were similar in terms of age $(\mathrm{t}=-0.98 ; \mathrm{p}>0.05)$. In addition, both groups were similar in terms of characteristics that could affect their levels of English proficiency (alma mater, attending a special course, taking private lessons, studying English abroad, living in English-speaking countries, speaking foreign languages other than English, and having parents working in the field of English Language Teaching (ELT)). Moreover, while a majority of the students from both groups self-reported their proficiency level as A2 (experimental 32 and control 34) in the self-assessment grid of the English Proficiency Background Form, a small number of the students self-reported as A1 (experimental 7 and control 5). According to these results, it can be said that both groups were similar in terms of English proficiency level.

\subsection{Instrumentation}

The following instruments were used:

\subsubsection{Maggie McVay Lynch Learning Style Inventory}

The Maggie McVay Lynch Learning Style Inventory, adapted into Turkish by Dağhan and Akkoyunlu (2011), was used to determine participants' learning styles. The inventory was administered to a similar group of 341 freshmen students to re-determine the reliability for the present study. The Cronbach Alpha internal consistency 
coefficient was calculated to be 0.86 for the total inventory; 0.71 for the Visual Learning Style sub-dimension; 0.77 for the Auditory Learning Style sub-dimension; and 0.76 for the Kinesthetic Learning Style sub-dimension.

\subsubsection{The English Reading Comprehension Test}

In order to measure the participants' reading comprehension achievement before and after the treatment, a 42-item four-choice multiple choice achievement test was constructed by the researcher. Champeau de Lopez, Marchi, and Arreaza-Coyle (1997) assert that multiple-choice questions distinguish reading from writing skills and have advantages like high corrector reliability, easy implementation, quick and easy collection, and easy determination of difficulty and discrimination levels. Rivers (1981) indicated that reading comprehension can be assessed validly through carefully developed multiple-choice items based on a reading passage; further pointing out that multiple-choice tests provide an objective way to assess reading comprehension in language classes and usually have four choices. Considering the purpose and scope of the study, it was decided that a multiple-choice test format was the most suitable way to objectively assess reading comprehension for the sake of this study. In the present study, for developing the achievement test, the following procedure was adopted by the researcher:

1) Considering participants' levels and needs, fourteen learning outcomes were developed based on the related literature and Common European Framework of Reference for languages (CEFR) published by the Council of Europe (2001); a table of specifications was constructed to guide the selection of items.

2) The Cognitive Process Dimension of the revised version of Bloom's taxonomy of educational objectives (Anderson \& Krathwohl, 2010) was used to develop test items. A minimum of two items per learning outcome were included in the 50-item multiple choice pilot form. Field experts' and English instructors' opinions were taken into consideration for the pilot form and required revisions were made.

3) The pilot form was administered to a total of 328 freshmen university students with low, intermediate, and high English proficiencies to compute test and item statistics.

4) After the pilot study, correct answers were coded as "1", any other responses were coded as " 0 ", and then item analysis was performed. Item difficulty and item discrimination indices were calculated for each item. Eight items which had an item discrimination index under 0.30 were eliminated from the test. Thereafter, the final form was constructed which comprised a total of 42 items, most of which had an average item difficulty (items with p-values around 0.50 ) in addition to the items that had a range of difficulty with high discrimination power.

5) The internal consistency reliability coefficient, using the Kuder-Richardson Formula 20 (KR-20), was 0.90. The average difficulty of the test was 0.50 and the average discrimination was 0.47 .

\subsubsection{Self-Efficacy Scale for English}

To test the second hypothesis, the Self-Efficacy Scale for English developed by Hanc1 Yanar and Bümen (2012) was used. According to Fraenkel et al. (2012), developing a good instrument takes a fair amount of time and effort, and requires a high level of skill; except in unusual cases, they recommend using an already developed instrument when appropriate. It was decided to use the Self-Efficacy Scale for English developed by Hanc1 Yanar and Bümen (2012) due to its being appropriate for the purpose of the study by including four language skills and having a high level of reliability and validity characteristics. The scale was administered to a similar sample group of 343 freshmen students to re-determine the reliability for the present study. The Cronbach Alpha internal consistency coefficient was calculated to be 0.96 for the total scale; 0.88 for Reading sub-dimension, 0.87 for Writing sub-dimension, 0.91 for Listening sub-dimension, and 0.86 for Speaking sub-dimension.

\subsubsection{English Proficiency Background Form}

This form was developed by the researcher to determine participants' English proficiency backgrounds. The first part of the form comprised personal information, such as the gender, name/surname, age, class and major. In the second part, there were questions to determine participants' background information that may affect their English proficiency levels at the time of the study. These questions sought information on the following issues:
1) Alma mater
2) Attending a special English course
3) Taking private English lessons
4) Studying English abroad
5) Living in English-speaking countries
6) Speaking foreign languages other than English 


\section{7) Having parents working in the field of ELT}

On the third part of the form, the Turkish version of the self-assessment grid included in the Language Passport was used; this is one of the three components of the European Language Portfolio published by the Council of Europe (2011). In this self-assessment grid, participants were asked to self-report their proficiency levels as A1, $\mathrm{A} 2, \mathrm{~B} 1, \mathrm{~B} 2, \mathrm{C} 1$, or $\mathrm{C} 2$.

\subsection{Limitations of the Study}

In evaluating the results of this study, there are several limitations that should be considered. One possible limitation is the limited time frame of a total of 8 weeks and 24 class hour time period excluding the pilot study, pre- and post-tests. The second limitation concerns the number of the participants ( 78 freshmen university students). Another limitation of the study is that reading comprehension activities were developed based on perceptual learning style preferences. But, as Dunn (1983) points out, learning style includes environmental, emotional, sociological, physical and psychological elements. It should be noted that the limited scope of the study prevents firm and widespread generalizations and further studies are needed with larger groups, over longer periods of time while considering different dimensions of learning style and reading comprehension activities.

\subsection{Data Collection}

The study was conducted between November 5, 2012 and December 28, 2012 and lasted for eight weeks. The Maggie McVay Lynch Learning Style Inventory, the English Reading Comprehension Test, the Self-Efficacy Scale for English, and the English Proficiency Background Form were administered to both experimental and control groups as pre-tests between October 22 and 26, 2012. Only the English Reading Comprehension Test and Self-Efficacy Scale for English were administered to both groups as post-tests again between December 31, 2012 and January 4, 2013.

Participants were given 50 minutes to complete the English Reading Comprehension Test, 30 minutes to complete the Self-Efficacy Scale for English, and 30 minutes to complete the Maggie McVay Lynch Learning Style Inventory and the English Proficiency Background Form.

\subsection{Data Analysis and Statistical Techniques}

The Maggie McVay Lynch Learning Style Inventory and the English Proficiency Background Form were analyzed using descriptive statistics (frequency and percentage). Because the Kolmogorov-Smirnov test showed that the Self-Efficacy Scale for English and the English Reading Comprehension Test scores had a normal distribution, and the variances were homogeneous, parametric statistics were used to analyze the data.

Independent samples t-tests were used to compare the Self-Efficacy Scale for English and the English Reading Comprehension pre-test scores between treatment and control groups. One-way analyses of covariance (ANCOVA) were conducted to compare the English Reading Comprehension Test and the Self-Efficacy Scale for English post-test scores, controlling for group differences on the pre-tests. Pearson's correlation coefficient was used to determine the relationship between English reading comprehension achievement and English self-efficacy. Statistical significance was set at a $P<0.05$ level, and statistical analysis was performed using SPSS for Windows (version 15.0, SPSS Inc. Chicago, IL, USA).

\subsection{Development of the Learning-Style Based Reading Comprehension Activities and the Procedure}

Learning-style based activities were developed by the course instructors; a total of eight texts were chosen-one for each week. In order to provide appropriate English texts for the study, the following criteria were adopted for the selection of the texts by considering the views of Villanueva de Debat (2006), Nuttall (2000), and Rivers (1981):

1) Selection of texts at an appropriate difficulty level

2) Containing appropriate and adequate syntactic structures

3) Avoiding overly long or short texts

4) Appropriateness to age and interest

5) Containing a reasonable amount of new information

In addition to these criteria, readability analysis was carried out using the online Text Content Analysis Tool ("Using English", 2013) to assess the difficulty of the texts. This tool gives statistics about a text including word count, unique words, number of sentences, average words per sentence, lexical density, and the Gunning Fog readability index. Xie (2005) indicates that the selection of reading material in foreign language classes should 
proceed from easy to difficult and in an orderly manner. It was considered appropriate to arrange texts from easy to difficult based on the results of the readability analyses.

This study and its activities were planned based on sensory (perceptual) learning styles owing to the fact that the dimension of sensory learning styles is one of the major style areas, according to the literature, that is thought to be particularly useful and relevant to language learning processes (Carrell et al., 1996; Cohen, 2003; Ehrman \& Oxford, 1990; Oxford, 2001; Reid, 1995).

First, participants' learning style preferences were determined using the Maggie McVay Lynch Learning Style Inventory. Participants' highest learning style scores were used as a measure of the dominant learning style. Scores indicated that 24 were visual learners, 11 were kinesthetic learners, and 4 were auditory learners. But when sub-dimension scores were analyzed in detail, the data showed that most of the participants had very close scores among the different learning style dimensions (visual, auditory, and kinesthetic). Therefore, this study intended to develop activities that meet the needs of different learning styles. Moreover, the literature (Cornet, 1983; Felder \& Henriques, 1995; Kinsella, 1995; Kroonenberg, 1995; Oxford, 2001; Oxford \& Lavine, 1992; Peacock, 2001; Rossi-Le, 1995) emphasizes that students must extend themselves beyond their style preferences, and so offering students a variety of activities to accommodate different learning styles is recommended. The tactile and kinesthetic learning styles are often combined and called "haptic" by some researchers (Oxford \& Lavine, 1992; Reid, 1995); furthermore, Oxford (2001) suggests similar activities for both tactile and kinesthetic learners. For this reason, reading comprehension activities were developed in common for both tactile and kinesthetic learners.

While developing the activities, for perceptual preferences, some recommendations and sample activities from the literature were used (Boydak, 2007; Eliason, 1995; Kroonenberg, 1995; Nelson, 1995; Oxford, 1995; Oxford, 2001; Peacock, 2001; Rossi-Le, 1995; Stebbins, 1995). Also, some activities were specifically developed for the study by the researcher. Finally, experts' (English lecturers with PhDs in ELT) opinions were obtained to improve the content validity of the reading program.

Most of the activities, such as a KWL (Know, Want, Learned) Table, mind maps, and videos, addressed different learning styles at the same time. The materials, methods, strategies, techniques, and instructional works used for different learning styles in the study could be summarized as follows:

Visual: pictures, colored pens, an overhead projector, strategic note-taking, writing important information on the board, silent reading, skimming, writing a poem or a motto, mind maps, finding key words (scanning), watching videos, highlighting text, story circle activity, map and chart completion, doing a crossword puzzle.

Auditory: CD player, group discussion, listening the text, oral instructions, using a KWL table, sequencing activity, playing taboo, presenting an oral summary, watching videos.

Kinesthetic and Tactile: group work, presenting works on the board, paragraph puzzle activity, role-play, strategic note-taking, fill in the blanks in the text, sequencing activity, playing taboo, map completion, highlighting text, drawing, mind maps, doing a crossword puzzle.

Reading comprehension activities addressing different learning styles (visual, auditory, kinesthetic/tactile) were developed and lesson plans were prepared for each week of the study. Jensen's (2001) explanations and the sample lesson plan provided at the end of the chapter were used as a guide for this study. Before the pre-reading phase, a short warm-up activity was included in the lesson plans in accordance with Jensen's (2001) suggestions.

Teaching was conducted during three one-hour sessions weekly, for a total of 24 hours over 8 weeks. Stebbins (1995) asserts that using groups in the classroom provides a more comfortable setting for students, enhances collaboration among students, and helps teachers monitor students more closely and provide more feedback. Participants were randomly divided into groups of 6 or 7 students because it was believed that group work would promote student participation and verbal interaction. Teaching reading in the classroom is generally divided into three phases: pre-reading, while-reading, and post reading (Alyousef, 2005; Beydoğan, 2010; Demirel, 2010; Epçaçan, 2009; Grabe, 1991; Grabe \& Stoller, 2001; Nuttall, 2000; Villanueva de Debat, 2006); accordingly, reading lessons were conducted through activities divided into three phases after a short warm-up period, as explained below:

Warm-up: This was intended to draw students' attention, motivate them, foster participation, and to ensure that students focused on the general theme of the text. With these aims in mind, and taking learning styles into consideration, open-ended discussion questions and group activities were used.

1) Pre-reading phase: Carrell and Eisterhold (1983) emphasize the significant role of providing background information in reading comprehension through pre-reading activities, especially at the beginning and 
intermediate proficiency levels and indicate that failure to activate an appropriate schema decreases comprehension of the text on the part of the reader. Accordingly, in the pre-reading phase, attempts were made to activate students' background knowledge, draw their attention, and to help them get ready for reading. For this purpose, activities requiring students to view pictures and captions, make guesses about the text, set their own reading purpose, notice keywords, brainstorm about keywords and concepts in the text, and identify the main idea(s) were conducted.

2) While-reading phase: The while-reading phase is intended to guide students through the text and to help them understand difficult concepts, make sense of complex sentences, consider relationships among ideas in the text, and to read purposefully and strategically (Grabe \& Stoller, 2001). In the present study, the while-reading phase involved guiding students to help them identify the main idea(s), supporting ideas, and details and to check the accuracy of their own predictions made during the pre-reading activities; activities such as silent reading, simultaneously reading while listening to the audio, note-taking, and highlighting important parts of the text were carried out in this phase. In addition, students were encouraged to guess the meaning of unknown words from the context.

3) Post-reading phase: This phase includes extending ideas and information from the text while also ensuring that the major ideas and supporting details are well understood (Grabe \& Stoller, 2001). In this study, students were required to comprehend the text fully and to use the content in other tasks by integrating other skills such as speaking or writing; activities such as filling in tables, revision of the mind maps prepared in the pre-reading phase, summarization, games, and watching videos were used.

Evaluation: At the end of each class, an evaluation was carried out using a different text on a similar topic and with the same target vocabulary.

A pilot study was carried out with two similar groups in order to identify any potential issues before beginning the study. Students in the pilot study groups were freshmen university students at Necmettin Erbakan University Ahmet Keleşoğlu Faculty of Education; they were required to take Foreign Language I \& II (English) classes like the study group. The pilot study was carried out between October 1-12, 2012 and both groups were taught by the same instructors. The same procedure as in the real study was followed in the pilot study. Based on the duration of the activities recorded during the pilot study, the estimated duration of the activities that would be required in the study was determined and final time changes on the detailed schedule were made.

In the control group, teaching took place during three one-hour sessions a week, for a total of eight weeks and lessons were conducted through activities divided into three phases after a short warm-up period with an evaluation part at the end of each class; the same as the experimental group. Unlike the experimental group, teaching was conducted in the traditional way without any attention to the learning styles as in the previous classes. Traditional reading classes are described as teacher-centered, dominated by teacher talk, and consist of activities which do not go far beyond simply reading the text and answering the comprehension questions about the text (Baturay \& Akar, 2007; Gömleksiz \& Elald1, 2011; Güngör \& Ün Açıkgöz, 2005). According to Al-Hajaya and Al-Khresheh (2012), the most common method of teaching students reading at the college level is through a traditional lecture in which there is a mismatch between students' learning preferences and instructional strategies, and students' learning preferences are rarely addressed.

\section{Results}

\subsection{Findings Regarding the First Hypothesis}

First hypothesis of the study was "Learning-style based activities improve reading comprehension achievement over traditional reading comprehension activities". A one-way ANCOVA was conducted to determine whether students' reading comprehension achievements significantly differed between the experimental and control groups after the treatment. As seen in Table 4, students' English Reading Comprehension post-test mean score was computed as being 18.74 for the control group and 22.33 for the experimental group. The English Reading Comprehension post-test modified mean score was 19.08 for the control group, and 22.00 for the experimental group. As for the groups' modified mean scores, it is clear that the differences are in favor of the experimental group. ANCOVA results to test the significance of the differences between the groups' modified post-test mean scores are given in Table 5 . 
Table 4. The English reading comprehension post-test mean and modified mean scores

\begin{tabular}{ccc}
\hline Groups & Mean & Modified Mean \\
\hline Control & 18.74 & 19.08 \\
Experimental & 22.33 & 22.00 \\
\hline
\end{tabular}

The ANCOVA result shows that the reading comprehension achievement of the experimental group was significantly better than that of the control group $\left[F_{(1,75)}=6.58, p<0.05\right]$, as shown in Table 5 .

Table 5. ANCOVA results of the English reading comprehension test

\begin{tabular}{cccccc}
\hline Variance Source & Sum of squares & Sd & MS & F & P \\
\hline Group & 164.58 & 1 & 164.58 & 6.58 & 0.01 \\
Pre-test Achievement & 718.66 & 1 & 718.66 & 28.74 & 0.00 \\
Error & 1875.44 & 75 & 25.01 & & \\
Total & 35748.00 & 78 & & & \\
\hline
\end{tabular}

\subsection{Findings Regarding the Second Hypothesis}

Second hypothesis of the study was "Learning-style based activities improve English self-efficacy perception over traditional reading comprehension activities". A one-way ANCOVA was conducted to determine if there were significant differences in English self-efficacy perception between the two groups after the treatment. As seen in Table 6, students' Self-Efficacy Scale for English post-test total mean score was 92.82 for the control group, and 101.15 for the experimental group. The Self-Efficacy Scale for English post-test modified mean score was computed as being 92.62 for the control group, and 101.36 for the experimental group. As for the groups' modified mean scores, it is clear that the differences are in favor of the experimental group. ANCOVA results to test the significance of the difference between the groups' modified post-test mean scores are provided in Table 7.

Table 6. Self-efficacy scale for English post-test mean and modified mean scores

\begin{tabular}{cccc}
\hline & Groups & Mean & Modified Mean \\
\hline \multirow{2}{*}{ Reading } & Control & 23.54 & 23.57 \\
& Experimental & 25.92 & 25.89 \\
\multirow{2}{*}{ Writing } & Control & 26.49 & 26.59 \\
& Experimental & 28.95 & 28.85 \\
\multirow{2}{*}{ Listening } & Control & 27.38 & 27.05 \\
& Experimental & 28.72 & 29.06 \\
Speaking & Control & 15.41 & 15.43 \\
& Experimental & 17.56 & 17.54 \\
Total & Control & 92.82 & 92.62 \\
& Experimental & 101.15 & 101.36 \\
\hline
\end{tabular}

As Table 7 shows, the ANCOVA result indicates that English self-efficacy of the experimental group was significantly higher than that of the control group $\left[F_{(1,75)}=8.77, p<0.05\right]$. 
Table 7. ANCOVA results of self-efficacy scale for English

\begin{tabular}{|c|c|c|c|c|c|}
\hline Variance Source & Sum of squares & Sd & MS & $\mathbf{F}$ & $\mathbf{P}$ \\
\hline Group & 105.64 & 1 & 105.64 & 9.64 & 0.00 \\
\hline Reading Pre-test & 540.69 & 1 & 540.69 & 49.35 & 0.00 \\
\hline Error & 821.77 & 75 & 10.96 & & \\
\hline Total & 49179.00 & 78 & & & \\
\hline Group & 99.94 & 1 & 99.94 & 5.63 & 0.02 \\
\hline Writing Pre-test & 945.77 & 1 & 945.77 & 53.26 & 0.00 \\
\hline Error & 1331.87 & 75 & 17.76 & & \\
\hline Total & 62322.00 & 78 & & & \\
\hline Group & 77.89 & 1 & 77.89 & 3.59 & 0.06 \\
\hline Listening Pre-test & 1062.80 & 1 & 1062.80 & 48.95 & 0.00 \\
\hline Error & 1628.32 & 75 & 21.71 & & \\
\hline Total & 64102.00 & 78 & & & \\
\hline Group & 86.94 & 1 & 86.94 & 6.10 & 0.02 \\
\hline Speaking Pre-test & 422.39 & 1 & 422.39 & 29.64 & 0.00 \\
\hline Error & 1068.63 & 75 & 14.25 & & \\
\hline Total & 22784.00 & 78 & & & \\
\hline Group & 1489.00 & 1 & 1489.00 & 8.77 & 0.00 \\
\hline Total Pre-test & 10931.03 & 1 & 10931.03 & 64.36 & 0.00 \\
\hline Error & 12737.80 & 75 & 169.84 & & \\
\hline Total & 758731.00 & 78 & & & \\
\hline
\end{tabular}

\subsection{Findings Regarding the Third Hypothesis}

Third hypothesis of the study was "There are positive correlations between English comprehension achievement and English self-efficacy". When the correlation between the Self-Efficacy Scale for English pre-test scores and the Reading Comprehension pre-test scores was analyzed, a significant correlation coefficient was found between reading comprehension achievement and Reading self-efficacy $(\mathrm{r}=0.44)$, Writing self-efficacy $(\mathrm{r}=0.37)$, Listening self-efficacy $(\mathrm{r}=0.42)$, Speaking self-efficacy $(\mathrm{r}=0.32)$, and total English self-efficacy $(\mathrm{r}=0.44)$ respectively. So, it is clear that before the experiment students with higher reading comprehension achievement had higher English self-efficacy perception. When the correlation between the Self-Efficacy Scale for English post-test scores and the Reading Comprehension post-test scores was analyzed, a significant correlation coefficient was found between reading comprehension achievement and Reading self-efficacy ( $\mathrm{r}=0.53$ ), Writing self-efficacy $(\mathrm{r}=0.46)$, Listening self-efficacy $(\mathrm{r}=0.45)$, Speaking self-efficacy $(\mathrm{r}=0.38)$, and total English self-efficacy $(\mathrm{r}=0.52)$ respectively. After the experiment, students with higher reading comprehension achievement had higher English self-efficacy perception as it was before the experiment.

As seen in Table 8, significant moderate positive correlations were found between English reading comprehension achievement and English self-efficacy. Therefore, it can be said that students with high English self-efficacy had higher reading comprehension achievement. Furthermore, learning-style based reading comprehension activities increased the correlation coefficient between reading comprehension achievement and English self-efficacy perception. 
Table 8. Correlation between English Self-Efficacy and reading comprehension achievement

\begin{tabular}{lccc}
\hline Self-efficacy & & Pre-test Achievement & Post-test Achievement \\
\hline \multirow{2}{*}{ Reading } & $\mathrm{r}$ & 0.44 & 0.53 \\
& $\mathrm{p}$ & 0.00 & 0.00 \\
Writing & $\mathrm{r}$ & 0.37 & 0.46 \\
& $\mathrm{p}$ & 0.00 & 0.00 \\
Listening & $\mathrm{r}$ & 0.42 & 0.45 \\
& $\mathrm{p}$ & 0.00 & 0.00 \\
Speaking & $\mathrm{r}$ & 0.32 & 0.38 \\
& $\mathrm{p}$ & 0.00 & 0.00 \\
Total & $\mathrm{r}$ & 0.44 & 0.52 \\
& $\mathrm{p}$ & 0.00 & 0.00 \\
\hline
\end{tabular}

\section{Discussion}

\subsection{Discussion of the First Hypothesis}

The findings indicate that the reading comprehension achievement of the experimental group was significantly higher than the control group. Based on this conclusion, it can be suggested that learning-style based activities are more effective on reading comprehension achievement than traditional reading comprehension activities designed without considering learning styles. This result is consistent with recent studies (Al-Hajaya \& Al-Khresheh, 2012; Khademi, Motallebzadeh, \& Ashraf, 2013; Sadeghi, Kasim, Tan, \& Abdullah, 2012) which emphasize the positive effects of instruction compatible with students' learning style preferences on their reading comprehension achievement in second/foreign language classes. Al-Hajaya and Al-Khresheh (2012) indicate that instructional strategies that are compatible with students' learning styles have a valuable role in enabling students to take control of their own learning and to maximize the potential for learning, and therefore contribute to reading comprehension. Sadeghi et al. (2012) approaches the relationship between learning styles and reading comprehension in foreign languages in terms of personality as the basis of learning styles. They assert individual differences such as learning styles and personality traits should be taken into account in foreign language reading classes. Khademi et al.'s (2013) results indicate that focusing on sensory preferences and providing related teaching strategies would be an applicable method for teaching reading and that using multisensory activities could help struggling readers.

The Reading Comprehension post-test scores showed an increase in the control group when compared to pre-test scores, though not statistically significant. This increase can be regarded as a relatively natural and expected consequence of the learning-teaching process to some extent. In other words, students continued to learn in the usual learning environment in which they feel comfortable.

It has been emphasized that learning-style based instruction is also effective in terms of developing reading skills in a first language (Carbo, 1984). Also, Grabe (2009) specifies that second language reading ability is comprised of both first and second language reading abilities and that first language ability has a very significant influence on second language reading ability. From this viewpoint, it can be said that the findings of the current study are consistent with the results of other relevant studies (Carbo, 1984; Williams, 2010) on first language reading instruction compatible with students' learning style preferences. For example, Carbo (1984) reports that reading comprehension instruction based on sensory learning styles significantly improves reading ability and attitudes towards reading. In Williams' (2010) study, a meaningful correlation was observed between sensory learning styles and reading comprehension, and it was concluded that a variety of techniques appealing to different modalities might be useful in improving reading comprehension. Also, more importantly, Dunn (1984) suggests that unlike traditional reading classes, reading instruction compatible with students' learning styles could be effective in enhancing the reading ability of students who have difficulties with reading.

Consistently positive results were obtained in the mentioned studies as to the importance of learning styles in the second/foreign language education and the significant effect of learning-style based instruction on the second/foreign language learning-teaching process was emphasized. In a meta-analysis study by Dunn, Griggs, Olson, Beasley, and Gorman (1995), it was specified that foreign language education is one of the areas which is 
most responsive to learning style accommodation. Additionally, Peacock (2001) reports that Reid's hypothesis that a mismatch between teaching and learning styles can cause learning failures and frustrations to be generally true for the students in his study. Peacock further suggests that matching learning and teaching styles can promote foreign language education. Güven's (2007) study confirms that learning-style based activities positively affect students' listening achievements, attitudes, and retention capacity. Based on their findings, Aliakbari and Tazik (2011) conclude that identifying students' learning styles can contribute to their foreign language achievement and students' learning preferences should be taken into account in foreign language classes. Kırkgöz and Doğanay (2003) point out the positive effect of accommodating different learning styles in foreign language classes. They further point to the difficulty of matching instruction to each individual's learning style preferences and suggest using varied language learning tasks, materials and strategies to accommodate different preferences in foreign language teaching.

This result of the study appears to be consistent with the opinions of De Florio-Hansen (2006); Ehrman et al., (2003); Felder and Henriques (1995); Oxford and Lavine (1992) that matching learning styles with the design of instruction will enhance learning and achievement in foreign language education. In addition, Wang and Jin (2008) highlight that learning style is crucial in the language learning process and designing instruction for learners with diverse learning styles is essential for effective teaching and learning processes, which is consistent with the results of our study. Besides foreign language education, a wide range of opinions exist in the literature as to the benefits of learning-style based instruction in the learning-teaching process. It is then appropriate to mention that this particular result of the study confirms the opinions of researchers such as Dunn, R. S. and Dunn, K. J. (1979); Dunn et al. (1995); Dunn et al. (2009); Given (1996), and Lovelace (2005). These studies assert that teaching that matches individual learning style preferences enhances learning and improves student achievement and motivation. Furthermore, some meta-analysis studies (Dunn et al., 1995; Lovelace, 2005) have reported the positive effects of learning-style based instruction on learning and achievement, which is also in line with this study.

However, results that are not in line with this finding and which suggest that learning-style based instruction is not necessary and will not improve students' achievement have also been reported. For example, Willingham's (2005) review of the literature pointed out that students differ in their perceptual preferences, but matching these preferences does not improve their academic achievement. According to their review, teachers should pay attention to the modality in which they present new material. In a similar vein, Sparks (2006) claims that identifying students' learning styles and matching instruction with styles does not improve learning in foreign language classes and argues that learning style models confuse ability with style.

Based on the relevant literature and findings of the present study, it is deemed significant for instructors in higher education to take students' learning styles into consideration in higher education English classes. Today, despite all the effort and investment, desired levels of language proficiency have not been achieved by many and major problems continue to exist in foreign language education in Turkey; so, it can be said that there are still deficiencies in the area of foreign language teaching. It is believed that one of the reasons for this deficiency might be expecting and forcing all students to learn in the same way in traditional learning environments which can also lead to a waste of time and effort in foreign language classes (Gömleksiz \& Sertdemir Düşmez, 2005; Işı, 2011). Dunn, R. S. and Dunn, K. J. (1979) emphasize the fact that many experienced and sensitive instructors are aware of students' different learning styles; however, they still continue to teach the same things in the same ways and expect all students to learn in the same ways and at the same time. In the current study, it is thought that improvements in student learning can be attributed to taking learning styles into consideration and consequently increasing motivation and interest towards learning.

\subsection{Discussion on the Second Hypothesis}

The findings indicated that the English self-efficacy of the experimental group was significantly higher than the control group. Based on this conclusion, it can be suggested that learning-style based activities are more effective at improving English self-efficacy perception than traditional reading comprehension activities designed without considering learning styles. It is believed that the positive effects on self-efficacy can be attributed to taking learning styles into consideration and designing learning experiences in a learner-centered way. In a similar vein, Rahimi and Abedini (2009) state that designing a learner-centered language curriculum can help language learners to develop positive self-efficacy perceptions. Also, Peacock (2001) reports that a match between learning styles and teaching styles can promote a positive attitude towards foreign languages. According to Ehrman et al. (2003), learning styles, learning strategies, and the affective domain are three inseparable categories that interact with each other when individual differences are considered. They further consider that using a learning-style based curriculum enables students to start the learning process in a more 
comfortable environment and without stress. Regarding Ehrman et al.'s opinions and the findings of the present study, it can be mentioned that in a language learning environment where learners' learning styles are taken into account, their self-efficacy will increase accordingly. Furthermore, this finding parallels the results obtained by Dunn et al. (2009), indicating that knowledge of learning styles improves students' self-efficacy towards their abilities and enhances their learning as a result of their increased efforts.

Though not statistically significant, the Self-Efficacy Scale for English post-test results showed an increase in the control group as well when compared to pre-test scores. Although teaching was conducted in the traditional way, the increase in students' self-efficacy can be regarded as a relatively natural and expected consequence of learning-teaching process in which students feel comfortable and safe.

This finding is in line with the opinions of Hazır Bıkmaz (2006) and Senemoğlu (2009) who argued that taking individual differences into account and adopting student-centered approaches will increase students' self-efficacy. Margolis and McCabe (2004) emphasize that students' perception of activities as interesting and valuable is one of the factors that can lead to an increase in self-efficacy. Accordingly, in this study, it is thought that activities became interesting and valuable for students by taking their learning styles into account and consequently, this increased participation and self-efficacy.

Based on the relevant literature and findings of the present study, it can be argued that activities designed by taking learning styles into account have a significant positive effect on students' self-efficacy in learning a foreign language (English in this context). As explained by Dunn, Babadoğan, Beudury, and Klavas (1991), by considering learning styles in the learning-teaching process it seems possible to meet students' individual learning needs. It is an expected result that students' self-efficacy increases when individual differences are considered as suggested by the researcher. According to Schunk and Pajares (2001), instructional variables influence students' self-efficacy to a certain extent. Therefore, considering learning styles in planning the learning-teaching process might be effective in increasing self-efficacy and in this way, it might contribute to foreign language learning and reading comprehension. Turanlı (2007) suggests that increasing self-efficacy and consequently increasing achievement is a significant requirement in foreign language classes. Based on the findings of the research, considering learning styles in foreign language classes might be beneficial in terms of increasing self-efficacy and so it is recommended to accommodate different learning styles in planning learning-teaching experiences.

\subsection{Discussion on the Third Hypothesis}

A significant moderate positive correlation was found between English reading comprehension achievement and English self-efficacy. This result suggests that there was a dynamic relationship between English self-efficacy and English reading comprehension achievement and students with high English self-efficacy had high reading comprehension achievement. In other words, it can be said that English self-efficacy had a significant effect on foreign language reading comprehension. In the literature, no studies were identified which explicitly investigated the relationship between English self-efficacy and English reading comprehension. However, bearing in mind that motivation incorporates self-efficacy, it can be said that this finding is consistent with the opinions of Grabe and Stoller (2001) and Grabe (2009) who argue that high motivation increases reading comprehension achievement both directly and indirectly through vast amounts of extensive reading. Similarly, Tsai (2012) reports that there is a significant relationship between motivation and foreign language reading achievement.

The aim of the third hypothesis was to investigate the relationship between English self-efficacy and English reading comprehension achievement. However, a significant moderate positive correlation was also found between reading self-efficacy and English reading comprehension achievement. Considering that learners can have different self-efficacy levels in four language skills (Hanc1 Yanar \& Bümen, 2012), the relationship between reading self-efficacy and English reading comprehension is an expected result. Therefore, it can be suggested that students with high reading self-efficacy also had high reading comprehension achievement. This finding is consistent with the results of studies by Gehonsooly and Elahi (2010) and Mills et al. (2006) which suggest that there is a significant relationship between self-efficacy in foreign language reading and foreign language reading achievement. Also, this finding is in accordance with the results of studies by Gahungu (2009); Hsieh and Schallert (2008); Magogwe and Oliver (2007); Mills, Pajares, and Herron (2007); Rahemi (2007); Tilfarlıoglu and Cinkara (2009); and Turanlı (2007) in the second/foreign language field which have reported a significant positive correlation between self-efficacy and achievement. Jabbarifar's (2011) review of the literature on the importance of self-efficacy in foreign language learning and its effect on achievement concluded that positive self-efficacy has a significant role in contributing to second or foreign language success, which is in 
line with our findings. The author further suggests that it is crucial to create a non-threatening and supportive instructional environment which could contribute to learners' second language self-efficacy. We think that learning-style based instruction could be a good option to create this kind of non-threatening learning environment in language classes.

It should be mentioned that other studies exist in the second/foreign language literature which have reported similar results for other language skills (e.g., listening and writing). In a study by Woodrow (2011), for example, it is reported that self-efficacy is a powerful predictor of writing performance and highly self-efficacious students perform well in their English writing. Büyükikiz (2011) indicates a significant relationship between writing skill and writing self-efficacy perception of students learning Turkish as a foreign language. Mills et al. (2006) report that listening self-efficacy was positively associated with listening proficiency only for female participants. At the end of their study, Rahimi and Abedini (2009) indicate that listening comprehension self-efficacy was significantly related to listening proficiency. Similarly, Chen (2007) reports that listening comprehension self-efficacy was significantly related to listening proficiency.

Similar results have been reported in various studies in fields other than foreign language education about the existing significant positive relationship between self-efficacy and achievement. Bandura (1993) emphasizes that self-efficacy significantly contributes to academic development. Also, in a study performed by Bandura, Barbaranelli, Caprara, and Pastorelli (1996), it was reported that self-efficacy beliefs and aspirations contribute to academic achievement. In many other studies the relationship between self-efficacy and academic achievement is emphasized and the positive effects of self-efficacy on learning and performance have also been observed (Alivernini \& Lucidi, 2011; Arslan, 2012; Margolis \& McCabe, 2004; Pajares, 2002; Pintrich \& De Groot, 1990; Sadi \& Uyar, 2013; Schunk \& Pajares, 2001). In addition, this finding is in accordance with researchers' opinions who suggest that self-efficacy has a positive effect on learning and achievement (Akiba \& Alkins, 2010; Hazır Bıkmaz, 2006; Mills et al., 2007; Zimmerman, 1995). Based on the results of this study and researchers' opinions, it can be said that higher foreign language (English) self-efficacy can positively affect foreign language reading achievement.

In the country of Turkey, some problems still exist in foreign language learning and teaching despite all the time and effort spent on foreign language education. More recently, however, various steps have been taken and particular practices have been adopted to prevent these problems. But it is thought that, cognitive factors such as cognitive styles, learning strategies, and prior knowledge are considered more often in this process. It needs to be considered that the problems in foreign language education may result from affective factors such as self-efficacy. It is believed that difficulty in using language fluently and effectively causes a kind of learned helplessness and disturbs the learning process by affecting self-efficacy in a negative way. With regard to the results of the current study, it can be said that self-efficacy should be taken into consideration in foreign language classes as a powerful predictor of achievement. As emphasized by Rossiter (2003), self-efficacy is essential in successful language learning. It can be suggested that strong self-efficacy may help contribute to foreign language learning achievement and reading comprehension ability as well as the other language skills.

\section{Conclusion}

This study provided empirical evidence on the positive effects of instruction compatible with students' learning style preferences on their reading comprehension achievement and English self-efficacy perceptions in foreign language classes. The findings of the present study also provided empirical evidence of positive relationships between English reading comprehension achievement and English self-efficacy. Based on the results of the study, it is recommended to use learning-style based activities to develop students' reading comprehension ability and to increase self-efficacy in higher education foreign language classes. Our results suggest that foreign language instruction in higher education institutions should attend to individual differences, including students' learning styles as proposed in this study. It is believed that taking learning styles into consideration as one of the individual differences that play an important role in learning and designing learning experiences accordingly will help to overcome the deficiencies in foreign language classes.

Although the current study provides important data regarding the effects of learning-style based activities on students' reading comprehension skills and self-efficacy perceptions in an English as a foreign language context, further research is still required to fully explore those activities' potential. Also, in the current study activities were designed based on the sensory perception dimension of the physiological aspects of learning style. Other learning style dimensions can also be taken into account in designing and practicing teaching activities. Moreover, the effects of learning-style based activities on other language abilities other than reading such as 
listening, speaking, or writing can be investigated. Finally, the effects of considering other individual differences such as motivation and language learning strategies on language learning achievement can be investigated.

\section{Acknowledgments}

This study was summarized from the PhD thesis of the author, "The Effects of Activities Based on Learning Styles of Students on Their Reading Comprehension Skills and Self-Efficacy Perceptions in English Foreign Language Classes" at Necmettin Erbakan University, Institute of Educational Sciences, Konya, Turkey.

\section{References}

Akiba, D., \& Alkins, K. (2010). Learning: The relationship between a seemingly mundane concept and classroom practices. The Clearing House, 83, 62-67. https://doi.org/10.1080/00098650903505357

Aktaş, T. (2004). Yabancı dil öğretiminde iletişimsel yeti. Selçuk Üniversitesi Sosyal Bilimler Enstitüsü Dergisi, $12,45-57$.

Al-Hajaya, N., \& Al-Khresheh, T. (2012). The effect of cognitive learning style-based reading program on the achievement of Jordanian freshmen English majors. International Education Studies, 5(3), 235-246. https://doi.org/10.5539/ies.v5n3p235

Aliakbari, M., \& Tazik, K. (2011). On the relationship between gender and perceptual language learning styles: The case of Iranian academic EFL learners. Educational Psychology: An International Journal of Experimental Educational Psychology, 31(6), 657-674. https://doi.org/10.1080/01443410.2011.592275

Alivernini, F., \& Lucidi, F. (2011). Relationship between social context, self-efficacy, motivation, academic achievement, and intention to drop out of high school: A longitudinal study. The Journal of Educational Research, 104, 241-252. https://doi.org/10.1080/00220671003728062

Alyousef, H. S. (2005). Teaching reading comprehension to ESL/EFL learners. The Reading Matrix, 5(2), 143-154.

Anderson, L. W., \& Krathwohl, D. R. (2010). Öğrenme ögretim ve değerlendirme ile ilgili bir sinıflama (D. A. Özçelik, Trans.). Ankara: Pagem Akademi. (Original work published 2001)

Arslan, A. (2012). İlköğretim öğrencilerinin öz yeterlik inancı kaynaklarının öğrenme ve performansla ilgili öz yeterlik inancını yordama gücü. Kuram ve Uygulamada Eğitim Bilimleri, 12(3), 1907-1914.

Bandura, A. (1993). Perceived self-efficacy in cognitive development and functioning. Educational Psychologist, 28(2), 117-148. https://doi.org/10.1207/s15326985ep2802_3

Bandura, A., Barbaranelli, C., Caprara, G. V., \& Pastorelli, C. (1996). Multifaceted impact of self-efficacy beliefs on academic functioning. Child Development, 67(3), 1206-1222. https://doi.org/10.2307/1131888

Baturay, M. H., \& Akar, N. (2007). A new perspective for the integration of skills to reading. Tömer Dil Dergisi, $136,16-27$.

Beydoğan, Ö. H. (2010). Okuma ve anlamayı etkileyen stratejiler. Milli Eğitim, 185, 8-21.

Boydak, H. A. (2007). Öğrenme stilleri (9th ed.). İstanbul: Beyaz Yayınları.

Bülbül, M. (2009). Yabancı dil eğitimi açısından karşılaştırmalı yazın çalışmalarının önemi. Atatürk Üniversitesi Sosyal Bilimler Enstitüsü Dergisi, 13(1), 191-199.

Büyükikiz, K. K. (2011). Türkçeyi yabancı dil olarak öğrenenlerin yazma becerileri ile öz yeterlilik algıları arasındaki iliş̧ki üzerine bir araştırma (Unpublished doctoral dissertation). Gazi Üniversitesi Eğitim Bilimleri Enstitüsü, Ankara.

Carbo, M. (1984). Research in learning style and reading: Implications for instruction. Theory into Practice, 23(1), 72-76. https://doi.org/10.1080/00405848409543092

Carrell, P. L., \& Eisterhold, J. C. (1983). Schema Theory and ESL reading pedagogy. TESOL Quarterly, 17(4), 553-573. https://doi.org/10.2307/3586613

Carrell, P. L., Prince, M. S., \& Astika, G. G. (1996). Personality types and language learning in an EFL context. Language Learning, 46(1), 75-99. https://doi.org/10.1111/j.1467-1770.1996.tb00641.x

Ceylan, H., \& Yorulmaz, M. (2010). The effect of the adaptation process to European Union on foreign language teacher training policies in Turkey. Trakya Üniversitesi Sosyal Bilimler Dergisi, 12(1), 116-127.

Champeau de Lopez, C. L., Marchi, G., \& Arreaza-Coyle, M. E. (1997). Taxonomy: Evaluating reading comprehension in EFL. Forum, 35(2), 30-37. 
Chen, H.-Y. (2007). The relationship between EFL learners' self-efficacy beliefs and English performance (Unpublished Doctoral Dissertation). The Florida State University College of Education, Tallahassee, Florida. Retrieved from http://diginole.lib.fsu.edu/cgi/viewcontent.cgi?article=2197\&context=etd

Cohen, A. D. (2003). The learner's side of foreign language learning: Where do styles, strategies, and tasks meet? IRAL, 41, 279-291. https://doi.org/10.1515/iral.2003.013

Cornet, C. E. (1983). What you should know about teaching and learning styles. Bloomington, Ind: Phi Delta Kapan: Fastback 191 (ERIC No: ED228235). Retrieved from http://files.eric.ed.gov/fulltext/ED228235.pdf

Council of Europe. (2001). Common European Framework of Reference for languages: Learning, Teaching, Assessment (CEFR) [Data file]. $\quad$ Retrieved http://www.coe.int/t/dg4/education/elp/elp-reg/Source/Key_reference/CEFR_EN.pdf

Council of Europe. (2011). European language portfolio (ELP) [Data file]. Retrieved from http://www.coe.int/t/dg4/education/elp/elp-reg/Source/assessement_grid/assessment_grid_turkish.pdf

Dağhan, G., \& Akkoyunlu, B. (2011). Maggie McVay Lynch Öğrenme Stili Envanterinin Türkçeye uyarlanma çalışması. Hacettepe Üniversitesi Ĕ̆itim Fakültesi Dergisi, 40, 117-126.

De Florio-Hansen, I. (2006). How to become a succesful language learner Learner autonomy, styles and strategies revisited. Dil Dergisi, 133, 29-59.

Demirel, Ö. (2010). Yabancı dil ögretimi. Dil pasaportu, dil biyografisi, dil dosyası (5th ed.). Ankara: Pegem A Yayincilik.

Dunn, R. (1983). Learning style and its relation exceptionality at both ends of the spectrum. Exceptional Children, 49(6), 496-506. https://doi.org/10.1177/001440298304900602

Dunn, R. (1984). Learning style: State of the science. Theory into Practice, 23(1), 10-19. https://doi.org/10.1080/00405848409543084

Dunn, R. S., \& Dunn, K. J. (1979). Learning styles/teaching styles: Should they...Can they...be matched? Educational Leadership, 36(4), 238-244.

Dunn, R., Babadoğan, C., Beudury, J., \& Klavas, A. (1991). Öğrenme stilleriyle ilgili araştırmaların taranması. Ankara Üniversitesi Ĕgitim Fakültesi Dergisi, 24(2), 603-619.

Dunn, R., Griggs, S. A., Olson, J., Beasley, M., \& Gorman, B. S. (1995). A meta-analytic validation of the Dunn and Dunn Model of Learning-Style Preferences. The Journal of Educational Research, 88(6), 353-362. https://doi.org/10.1080/00220671.1995.9941181

Dunn, R., Honigsfeld, A., Doolan, L. S., Bostrom, L., Russo, K., Schiering, M. S., ... Tenedero, H. (2009). Impact of learning-style instructional strategies on students' achievement and attitudes: Perceptions of educators in diverse institutions. The Clearing House, 82(3), 135-140. https://doi.org/10.3200/TCHS.82.3.135-140

Ehrman, M. E., Leaver, B. L., \& Oxford, R. L. (2003). A brief overview of individual differences in second language learning. System, 31, 313-330. https://doi.org/10.1016/S0346-251X(03)00045-9

Ehrman, M., \& Oxford, R. (1990). Adult language learning styles and strategies in an intensive training setting. The Modern Language Journal, 74(3), 311-327. https://doi.org/10.1111/j.1540-4781.1990.tb01069.x

Ekici, G. (2003). Öğrenme stiline dayalı ögretim ve biyoloji dersi ögretimine yönelik ders planı örnekleri. Ankara: Gazi Kitabevi.

Eliason, P. A. (1995). Difficulties with cross-cultural learning styles assessment. In J. Reid (Ed.), Learning styles in the ESL/EFL classroom (pp. 19-33). Boston, MA: Heinle and Heinle Publishers.

Epçaçan, C. (2009). Okuduğunu anlama stratejilerine genel bir bakış. Uluslararası Sosyal Araştırmalar Dergisi, 2(6), 207-223.

Er, A. (2005). Yabanc1 dil eğitiminde "okuma”. Journal of Kazım Karabekir Education Faculty, 12, 208-218.

Felder, R. M., \& Henriques, E. R. (1995). Learning and teaching styles in foreign and second language education. Foreign Language Annals, 28(1), 21-31. https://doi.org/10.1111/j.1944-9720.1995.tb00767.x

Fraenkel, J. R., Wallen, N. E., \& Hyun, H. H. (2012). How to design and evaluate research in education (8th ed.). New York, NY: McGraw-Hill. 
Gahungu, O. (2009). Are self-efficacy, language learning strategies, and foreign language ability interrelated? The Buckingham Journal of Language and Linguistics, 2(1), 47-60.

Gehonsooly, B., \& Elahi, M. (2010). Learners' self-efficacy in reading and its relation to foreign language reading anxiety and reading achievement. Journal of English Language Teaching and Learning, 53(217), 45-67.

Genç, A. (2003). The importance of reading and dictionary use in foreign language learning. Hacettepe University Journal of Education, 25, 104-108.

Given, B. K. (1996). Learning styles: A synthesized model. Journal of Accelerated Learning and Teaching, 21(1\&2), 11-43.

Gömleksiz, M. N. (2002). Üniversitelerde yürütülen yabanc1 dil derslerine ilişkin öğrenci görüşlerinin değerlendirilmesi (Fırat Üniversitesi örneği). Firat Üniversitesi Sosyal Bilimler Dergisi, 12(1), 143-158.

Gömleksiz, M. N., \& Elaldı, Ş. (2011). Yapılandırmacı yaklaşım bağlamında yabancı dil öğretimi. Turkish Studies-International Periodical for the Languages, Literature and History of Turkish or Turkic, 6(2), 443-454.

Gömleksiz, M. N., \& Sertdemir Düşmez, O. (2005). İngilizce'de Relative Clause konusunun öğretiminde bilgisayar destekli öğretim ile geleneksel yöntemin öğrenci başarısı üzerine etkisinin karşılaştırılması. Türk Eğitim Bilimleri Dergisi, 3(2), 163-179.

Grabe, W. (1991). Current developments in second language reading research. Tesol Quarterly, 25(3), 375-396. https://doi.org/10.2307/3586977

Grabe, W. (2009). Reading in a second language: Moving from theory to practice. New York, NY: Cambridge University Press.

Grabe, W., \& Stoller, F. L. (2001). Reading for academic purposes: Guidelines for the ESL/EFL teacher. In M. Celce-Murcia (Ed.), Teaching English as a second or foreign language (pp. 187-203). Boston, MA: Heinle and Heinle Publishers.

Güler, G. (2005). Avrupa Konseyi Ortak Dil Kriterleri Çerçeve Programı ve Türkiye'de yabancı dil öğretim süreçleri. Trakya Üniversitesi Sosyal Bilimler Dergisi, 6(1), 89-106.

Gündoğdu, M. (2005). Avrupa Birliği yolunda Türkiye'nin yabancı dil politikası. Çukurova Üniversitesi Ĕ̆itim Fakültesi Dergisi, 2(29), 120-127.

Güngör, A., \& Ün Açıkgöz, K. (2005). İşbirlikli öğrenme ve geleneksel öğretimin okuduğunu anlama üzerinde etkileri ve cinsiyet ile ilişkileri. Kuram ve Uygulamada Eğitim Yönetimi, 43, 354-378.

Güven, Z. Z. (2007). Öğrenme Stillerine Dayalı Etkinliklerin Öğrencilerin Dinleme Becerisi Erişileri, Ingilizce Dersine Yönelik Tutumları ve Öğrenilenlerin Kalıcılı̆̆ına Etkisi (Unpublished doctoral dissertation). Selçuk Ünversitesi Sosyal Bilimler Enstitüsü, Konya.

Hancı Yanar, B., \& Bümen, N. T. (2012). İngilizce ile ilgili özyeterlik inancı ölçeğinin geliştirilmesi. Kastamonu Eğitim Dergisi, 20(1), 97-110.

Hazır Bıkmaz, F. (2006). Öz yeterlik inançları. In Y. Kuzgun, \& D. Deryakulu (Eds.), Eğitimde bireysel farklılıklar (pp. 291-310). Ankara: Nobel Yayın Dağıtım.

Hsieh, P.-H., \& Schallert, D. L. (2008). Implications from self-efficacy and attribution theories for an understanding of undergraduates' motivation in a foreign language course. Contemporary Educational Psychology, 33(4), 513-532. https://doi.org/10.1016/j.cedpsych.2008.01.003

Işık, A. (2011). Language education and Elt materials in Turkey from the Path Dependence Perspective. Hacettepe University Journal of Education, 40, 256-266.

Jabbarifar, T. (2011). The importance of self-efficacy and foreign language learning in the 21 st century. Journal of International Education Research, 7(4), 117-126. https://doi.org/10.19030/jier.v7i4.6196

Jensen, L. (2001). Planning lessons. In M. Celce-Murcia (Ed.), Teaching English as a second or foreign language (pp. 403-413). Boston, MA: Heinle and Heinle Publishers.

Karakaya, Z. (2007). Yabancı dil öğretiminde bir ders modeli: Öğreterek öğrenme. Milli Eğitim, 174, $28-42$. 
Khademi, M., Motallebzadeh, K., \& Ashraf, H. (2013). The relationship between Iranian EFL instructors' understanding of learning styles and their students' sucsess in reading comprehension. English Language Teaching, 6(4), 134-142. https://doi.org/10.5539/elt.v6n4p134

Kinsella, K. (1995). Understanding and empowering diverse learners in ESL classrooms. In J. Reid (Ed.), Learning styles in the ESL/EFL classroom (pp. 170-194). Boston, MA: Heinle and Heinle Publishers.

Kırkgöz, Y., \& Doğanay, A. (2003). Exploring learning style and hemispheric processing preferences of EFL Learners. Çukurova Üniversitesi Ĕ̈itim Fakültesi Dergisi, 2(24), 35-48.

Kroonenberg, N. (1995). Meeting language learners' sensory-learning-style preferences. In J. Reid (Ed.), Learning styles in the ESL/EFL classroom (pp. 74-86). Boston, MA: Heinle and Heinle Publishers.

Levine, A., Ferenz, O., \& Reves, T. (2000). EFL academic reading and modern technology: How can we turn our students into independent critical readers? TESL-EJ, 4(4), 1-9.

Lovelace, M. K. (2005). Meta-analysis of experimental research based on the Dunn and Dunn Model. The Journal of Educational Research, 98(3), 176-183. https://doi.org/10.3200/JOER.98.3.176-183

Magogwe, J. M., \& Oliver, R. (2007). The relationship between language learning strategies, proficiency, age and self-efficacy beliefs: A study of language learners in Botswana. System, 35, 338-352. https://doi.org/10.1016/j.system.2007.01.003

Margolis, H., \& McCabe, P. P. (2004). Self-efficacy: A key to improving the motivation of struggling learners. The Clearing House, 77(6), 241-249. https://doi.org/10.3200/TCHS.77.6.241-249

Mills, N., Pajares, F., \& Herron, C. (2006). A reevaluation of the role of anxiety: Self-efficacy, anxiety, and their relation to reading and listening proficiency. Foreign Language Annals, 39(2), 276-295. https://doi.org/10.1111/j.1944-9720.2006.tb02266.x

Mills, N., Pajares, F., \& Herron, C. (2007). Self-efficacy of college intermediate French students: Relation to $\begin{array}{llll}\text { achievement and motivation. Language Learning, 57(3), 417-442. } & \text {. }\end{array}$ https://doi.org/10.1111/j.1467-9922.2007.00421.x

Nelson, G. L. (1995). Cultural differences in learning styles. In J. Reid (Ed.), Learning styles in the ESL/EFL classroom (pp. 3-18). Boston, MA: Heinle and Heinle Publishers.

Nuttall, C. (2000). Teaching reading skills in a foreign language. Oxford, UK: Macmillan Heinemann.

Oxford, R. L. (1989). The role of styles and strategies in second language learning. Retrieved from http://files.eric.ed.gov/fulltext/ED317087.pdf

Oxford, R. L. (1995). Gender differences in language learning styles: What do they mean? In J. Reid (Ed.), Learning styles in the ESL/EFL classroom (pp. 34-46). Boston, MA: Heinle and Heinle Publishers.

Oxford, R. L. (2001). Language learning styles and strategies. In M. Celce-Murcia (Ed.), Teaching English as a second or foreign language (pp. 359-366). Boston, MA: Heinle and Heinle Publishers.

Oxford, R. L., \& Ehrman, M. (1992). Second language research on individual differences. Annual Review of Applied Linguistics, 13, 188-205. https://doi.org/10.1017/S0267190500002464

Oxford, R. L., \& Lavine, R. Z. (1992). Teacher-student style wars in the language classroom: Research insights and suggestions. ADFL Bulletin, 23(2), 38-45. https://doi.org/10.1632/adfl.23.2.38

Özpolat, V. (2013). The place of student-centered approach in teachers' occupational priorities. National Education, 200, 5-27.

Pajares, F. (2002). Overview of social cognitive theory and of self-efficacy. Retrieved from http://www.uky.edu/ eushe2/Pajares/eff.html

Peacock, M. (2001). Match or mismatch? Learning styles and teaching styles in EFL. International Journal of Applied Linguistics, 11(1), 1-20. https://doi.org/10.1111/1473-4192.00001

Pintrich, P. R., \& De Groot, E. V. (1990). Motivational and self-regulated learning components of classroom academic performance. Journal of Educational Psychology, 82(1), 33-40. https://doi.org/10.1037/0022-0663.82.1.33

Rahemi, J. (2007). Self-efficacy in English and Iranian senior high school students majoring in humanities. Novitas-ROYAL, 1(2), 98-111. 
Rahimi, A., \& Abedini, A. (2009). The interface between EFL learners' self-efficacy concerning listening comprehension and listening proficiency. Novitas-ROYAL, 3(1), 14-28.

Reid, J. M. (1995). Preface. In J. Reid (Ed.), Learning styles in the ESL/EFL classroom (pp. viii-xvii). Boston, MA: Heinle and Heinle Publishers. https://doi.org/10.1017/CBO9781139172721.001

Rivers, W. M. (1981). Teaching foreign language skills (2nd ed.). Chicago, IL: The University of Chicago Press.

Rossi-Le, L. (1995). Learning styles and strategies in adult immigrant ESL students. In J. Reid (Ed.), Learning styles in the ESL/EFL classroom (pp. 118-125). Boston, MA: Heinle and Heinle Publishers.

Rossiter, M. J. (2003). The effects of affective strategy training in the ESL classroom. TESL-EJ, 7(2), 1-20.

Sadeghi, N., Kasim, Z. M., Tan, B. H., \& Abdullah, F. S. (2012). Learning styles, personality types and reading comprehension performance. English Language Teaching, 5(4), 116-123. https://doi.org/10.5539/elt.v5n4p116

Sadi, Ö., \& Uyar, M. (2013). The relationship between self-efficacy, self-regulated learning strategies and achievement: A path model. Journal of Baltic Science Education, 12(1), 21-33.

Schunk, D. H., \& Pajares, F. (2001). The development of academic self-efficacy. Retrieved from http://www.uky.edu/ eushe2/Pajares/SchunkPajares2001.PDF

Senemoğlu, N. (2009). Gelişsim, ögrenme ve ögretim: Kuramdan uygulamaya (14th ed.). Ankara: Pegem A Yayıncilik.

Skehan, P. (1989). Individual differences in second-language learning. London: Edward Arnold.

Sparks, R. L. (2006). Learning styles-Making too many "wrong mistakes": A response to Castro and Peck. Foreign Language Annals, 39(3), 520-528. https://doi.org/10.1111/j.1944-9720.2006.tb02903.x

Stebbins, C. (1995). Culture-specific perceptual-learning-style preferences of postsecondary students of English as a second language. In J. Reid (Ed.), Learning styles in the ESL/EFL classroom (pp. 108-117).

Tilfarlığlu, F., \& Cinkara, E. (2009). Self-efficacy in EFL: Differences among proficiency groups and relationship with success. Novitas-ROYAL, 3(2), 129-142.

Tsai, Y.-R. (2012). Investigating the relationships among cognitive learning styles, motivation and strategy use in reading English as a foreign language. International Journal of Business and Social Science, 3(13), 188-197.

Turanlı, A. S. (2007). Sosyal bilişsel öğrenme ve yabancı dil öğretimi. Erciyes Üniversitesi Sosyal Bilimler Enstitüsü Dergisi, 23(2), 1-16. Retrieved from http://sbe.erciyes.edu.tr/dergi/sayi_23/sayi_23.htm

Using English (UE). (2013). English as a second language online. Retrieved from $\mathrm{http} / / / \mathrm{www}$. usingenglish.com/resources/text-statistics.php

Üstünlüoğlu, E. (2008). A brief account of language teacher training and teaching from other countries. Milli Eğitim, 179, 322-332.

Villanueva de Debat, E. (2006). Applying current approaches to the teaching of reading. English Teaching Forum, 44(1), 8-15.

Wang, M., \& Jin, G. (2008). Learning styles and English teaching. Us-China Foreign Language, 6(5), 30-33.

Williams, J. (2010). Reading Comprehension, Learning Styles, and Seventh Grade Students (Unpublished Doctoral Dissertation). Liberty University the Faculty of the School of Education, Lynchburg, Virginia, United States.

Willingham, D. T. (2005). Ask the Cognitive scientist: Do visual, auditory, and kinesthetic learners need visual, auditory, and kinesthetic instruction? American Educator, 29(2), 31-35. Retrieved from http://www.aft.org/newspubs/periodicals/ae/summer2005/willingham.cfm

Woodrow, L. (2011). College English writing affect: Self-efficacy and anxiety. System, 39, 510-522. https://doi.org/10.1016/j.system.2011.10.017

Xie, X. (2005). The influence of schema theory on foreign language reading comprehension. The English Teacher, 34, 67-75.

Zimmerman, B. J. (1995). Self-efficacy and educational development. In A. Bandura (Ed.), Self-efficacy in changing societies (pp. 202-231). Cambridge: Cambridge University Press. https://doi.org/10.1017/CBO9780511527692.009 


\section{Copyrights}

Copyright for this article is retained by the author(s), with first publication rights granted to the journal.

This is an open-access article distributed under the terms and conditions of the Creative Commons Attribution license (http://creativecommons.org/licenses/by/4.0/). 